\title{
New species of cave-dwelling beetles (Coleoptera: Carabidae: Trechinae) from the Azores
}

\author{
P. A. V. BORGES*†t, A. R. M. SERRANO§ and I. R. AMORIM- \\ $\dagger$ Universidade dos Açores, Dep. Ciências Agrárias, CITA-A, 9700-851 \\ Angra do Heroísmo, Terceira, Açores, Portugal; e-mail: pborges@ \\ angra.uac.pt \\ †Unidade de Macroecologia e Conservação (UMC), Universidade de \\ Évora, Fábrica dos Leões, 7000-730 Évora, Portugal \\ $\S$ Faculdade de Ciências de Lisboa (DZA), Centro de Biologia \\ Ambiental, R. Ernesto de Vasconcelos, Ed. C2, $3^{\circ}$ Piso, Campo \\ Grande, P-1749-016 Lisboa, Portugal \\ - University of California, Los Angeles, Department of Organismic \\ Biology, Ecology and Evolution, 621 Charles E. Young Dr. So., Box \\ 951606, Los Angeles, CA 90095-1606, USA
}

\section{(Accepted 25 October 2002)}

The cave-dwelling beetles, Trechus pereirai, new species, and Trechus oromii, new species, and the epigean Trechus terrabravensis, new species, from the Azores islands are described. The male of the cave-dwelling beetle Trechus jorgensis Oromí and Borges is described for the first time. Affinities between Trechus species from the Azores and from other Macaronesian archipelagoes are discussed based on the morphology of the aedeagus. Ecological data are also included.

Nesta contribuição são descritos para os Açores os escaravelhos cavernícolas, Trechus pereirai, nova espécie, e Trechus oromii, nova espécie, e ainda o escaravelho epígeo Trechus terrabravensis, nova espécie. É feita pela primeira vez a descrição do macho da espécie cavernícola Trechus jorgensis Oromí \& Borges. Com base na morfologia da genitália masculina são discutidas as afinidades com as outras espécies de Trechus dos Açores e outros arquipélagos Macaronésicos. Incluem-se ainda dados ecológicos.

Keywords: Azores, groundbeetles, Coleoptera, Trechus.

\section{Introduction}

The Azores, an archipelago of nine islands located in the North Atlantic, is rich in lava tubes and volcanic pits that are inhabited by an interesting troglobitic fauna (see Borges and Oromí, 1991, 1994). Groundbeetles (Coleoptera, Carabidae) are the

*To whom correspondence is addressed (at Universidade dos Açores). 
most diverse troglobitic group known to occur in these islands, with seven species of Trechinae occurring on five of the islands. These include: Thalassophilus azoricus Oromí and Borges (S. Miguel); Trechus terceiranus Machado (Terceira); Trechus jorgensis Oromí and Borges (S. Jorge); Trechus picoensis Machado, Trechus montanheirorum Oromí and Borges, Trechus pereirai n. sp. (Pico); and Trechus oromii n. sp. (Faial) (see Machado, 1988; Oromí and Borges, 1991).

Epigean relatives of the cave beetle fauna have been collected from only two of the islands: Trechus torretassoi Jeannel from the margins of two large lakes on S. Miguel and Trechus terrabravensis $\mathrm{n}$. sp. from the native laurel forests on Terceira.

Due to the limited knowledge of the Azorean arthropods (see Borges et al., 2000), we have intensively surveyed 16 Natural Forest Reserves (BALA, 'Biodiversity of Arthropods of the Laurisilva of the Azores' project; 1999 and 2000) in seven of the nine Azorean islands. In addition, several biospeleological expeditions were carried out on seven of the islands looking for troglobitic groundbeetles in lava tubes, volcanic pits and mesovoid shallow substratum (MSS) (see Culver 2001). As a result, three new species of Trechus and the unknown male of Trechus jorgensis Oromí and Borges have been collected.

In this contribution we describe new Trechus taxa and provide a key for the identification of the Trechus species from the Azores. All material is deposited in the University of the Azores at Terceira. A phylogeographic study of the Azorean Trechus based on mitochondrial DNA sequence will be presented elsewhere (Amorim et al., in preparation).

\section{Species descriptions}

Trechus terrabravensis Borges, Serrano and Amorim, new species (figure 1)

\section{Diagnosis}

Dark pigmentation, with some lighter parts; normal and convex eyes; wingless; lateral furrows of pronotum narrower than other Azorean species. Integument wellpigmented with pronotum darker than elytra. Appendages less pigmented (light brown), with tibiae and tarsomeres darker than femora. First antennomere slightly brown and the remaining darker. Epipleura light brown and abdomen brown. Subnitidous with pronotum and head brighter. Microreticulation isodiametric on the head, but transverse on the pronotum and on the elytra.

\section{Type series}

Holotype: $\hat{\jmath}$, Açores, Terceira, Terra-Brava, 18 July-2 August 2001 (P. A. V. Borges and F. Pereira). PARATYPES: 2o+o, same locality as holotype, 5-19 May 1998, 1-15 August 1998 (D. Silva).

Note. In addition one male and four females were collected in the same locality for molecular analysis. These are also used for measures. Additional specimens were recently collected in another locality at Terceira (Caldeira da Serra de Santa Bárbara). 

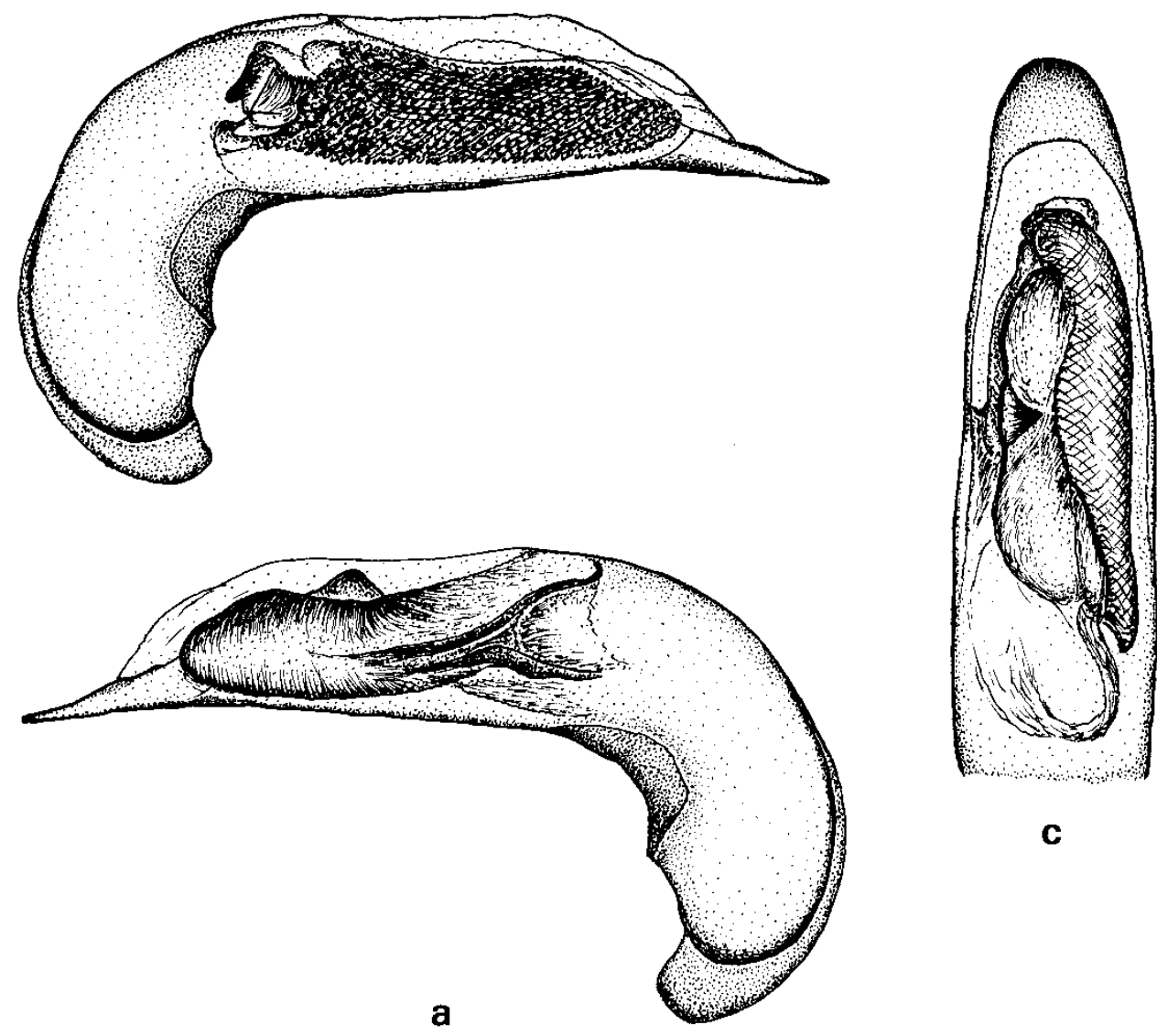

C
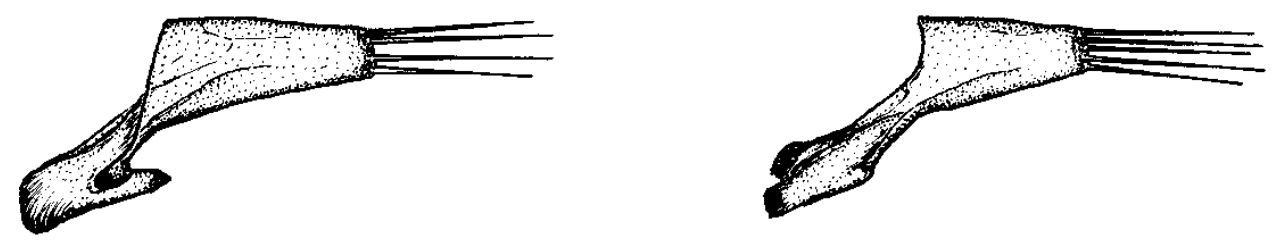

b

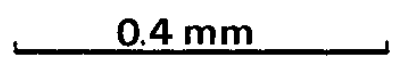

FIG. 1. Aedeagus of Trechus terrabravensis n. sp. (a) Median lobe, lateral view; (b) left and right parameres; (c) median lobe, dorsal view. Scale: $0.4 \mathrm{~mm}$.

\section{Description}

Length of holotype: $3.85 \mathrm{~mm}$. Length of remaining specimens: $3.36-3.76 \mathrm{~mm}$. Medium size, convex and ovalate.

Head almost $1.13 \times$ as wide as long, $0.76 \times$ narrower than pronotum; eyes welldeveloped, convex, diameter of eyes $2.4 \times$ larger than temples; temples with microchaetae. Frons highly convex, the frontal furrows deeply curved and rounded, with darker pigmentation. Anterior margin of labrum very concave. Maxillary palpi long and slender. Chaetotaxy: two pairs of supraocular setae; four setae in clypeus 
(outer ones larger); six setae on labrum, the outer ones being the largest. Antennae $2.05 \mathrm{~mm}$ long (others: $1.80-1.98 \mathrm{~mm}$ ), surpassing only the first quarter of elytra; the 3 rd antennomere subequal to the $2 \mathrm{nd}$; 1 st to 6 th antennomere $2 \times$ longer than wide, 7 th antennomere $1.66 \times$ longer than wide, 8 th to 10 th antennomere $1.3 \times$ longer than wide, 11 th antennomere $2.36 \times$ longer than wide. Pronotum convex, cordiform, highly transverse, $1.29 \times$ as broad as long (others: $1.27-1.35 \times$ ); side margins curved till hind angle; anterior angles obtuse; hind angles obtuse, well marked and not protruding; basal border emarginated; lateral furrows narrower than in the other Azorean Trechus; basal fovea well marked. Chaetotaxy: the anterior setae is located in anterior quarter and the posterior seta located in the hind angle. Elytra ovate with rounded shoulders, $1.58 \times$ wider than pronotum (others: $1.48-1.60 \times$ ) and $1.44 \times$ as long as broad (others: $1.35-1.48 \times$ ); apex rounded, lateral furrows canaliculated; striae all well marked and interstriae convex. Recurrent striae well connected to the 5th. Chaetotaxy: umbilical series typical of Trechus; preapical seta equidistant of suture and apex; the first discal seta in the 3rd stria is located in the anterior quarter and the second discal seta approximately in the centre.

Aedeagus with apex of median lobe straight and pointed (lateral view) (figure 1a); apex rounded (dorsal view) (figure 1c). Left and right parameres with four and five setae each, respectively (figure 1b).

\section{Ecological notes}

All specimens were collected by means of pitfall traps baited with Turquin (a mixture of dark beer with preservatives) or liver, located deep inside very humid laurel forests on Terceira. More recently, several specimens were collected in leaf litter, suggesting that this is a litter species. In both Terra-Brava and Caldeira da Serra de Santa Bárbara, the terrain is basaltic with a system of cracks and deep holes and the forest floor is covered by a dense carpet of mosses and ferns with little light reaching the ground.

\section{Taxonomic notes}

The aedeagus of this new species clearly resembles those of the cavernicolous troglobitic species Trechus jorgensis (S. Jorge) and T. pereirai n. sp. (Pico).

\section{Trechus pereirai Borges, Serrano and Amorim, new species} (figure 2)

\section{Diagnosis}

Elytra and pronotal disc slightly pigmented; elytra apical angles almost straight. Eyes reduced. Elytra and pronotal disc slightly pigmented; appendages depigmented. Microreticulation isodiametric, though not very clear. In general darker than T. picoensis, T. jorgensis and T. oromii.

\section{Type series}

Holotype: ^ૈ, Açores, Pico, Gruta do Tio Joaquim, Ribeirinha, 29 June-16 July 2000 (I. Amorim and F. Pereira). PARAtype: 19, Açores, Pico, Gruta das 

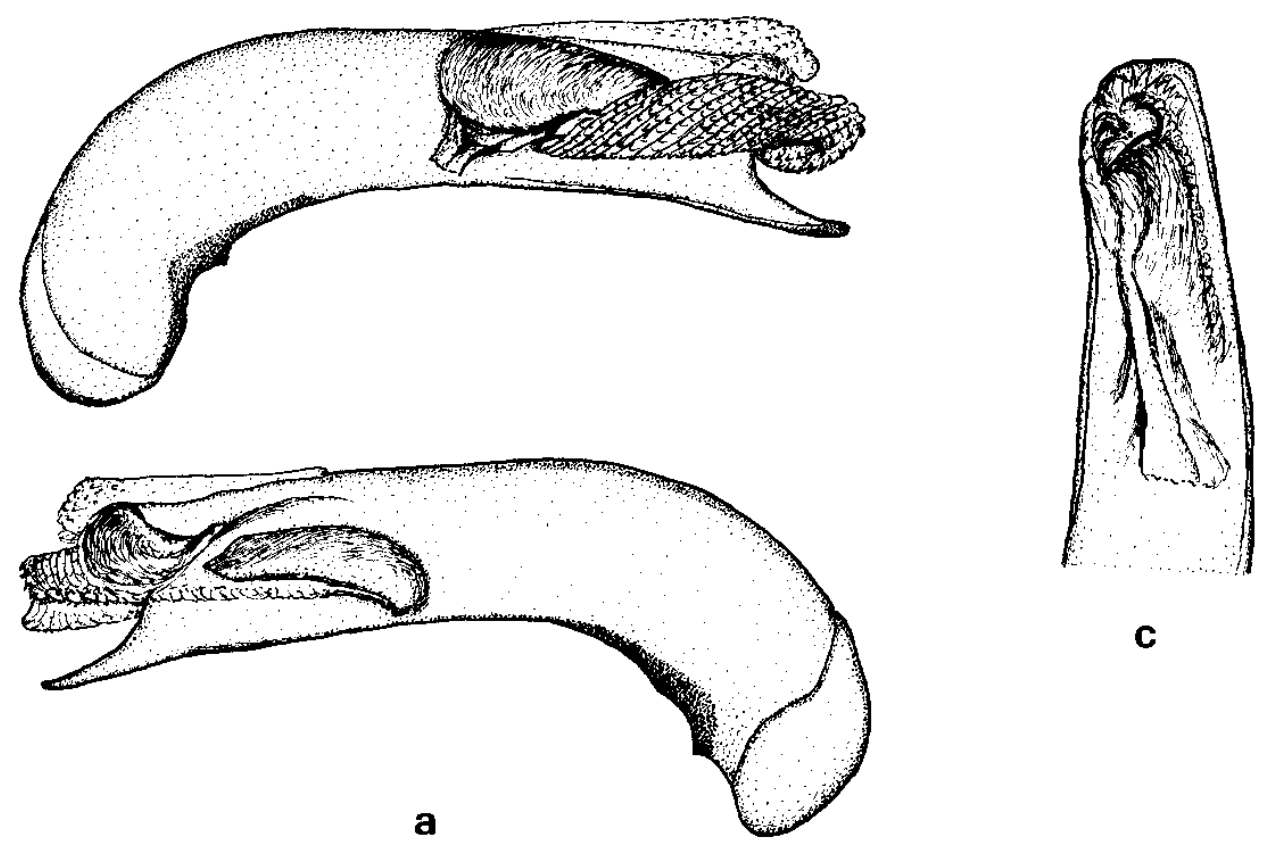

C
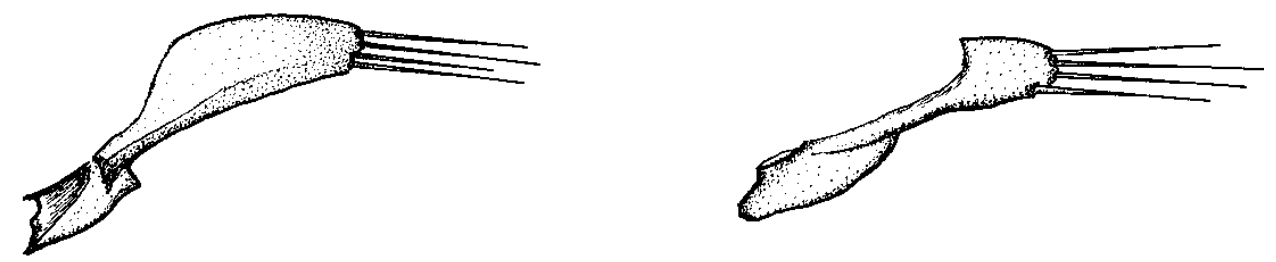

b

\section{$0.3 \mathrm{~mm}$}

FIg. 2. Aedeagus of Trechus pereirai $\mathrm{n}$. sp. (a) Median lobe, lateral view; (b) left and right parameres; (c) median lobe, dorsal view. Scale: $0.3 \mathrm{~mm}$.

Cabras (Terra), Terra do Pão, S. Caetano, 18-25 August 2001 (I. Amorim and F. Pereira).

Note. In addition three males and one female were collected in Gruta das Cabras (Terra) for molecular analysis. These are also used for measures.

\section{Description}

Length of holotype: $3.20 \mathrm{~mm}$. Length of other specimens: $3.02-3.19 \mathrm{~mm}$. Small, convex and ovalate.

Head normal, ovate, frontal furrows deep and curved; frons convex as in the other Azorean Trechus, but the orbitals flatter in their anterior part; eyes small and reduced, slightly convex, the diameter as long as temples. Temples curved as in $T$. jorgensis. Labrum arcuated. Maxillary palpi long and slender. Chaetotaxy: as in T. terrabravensis n. sp. Antennae $1.76 \mathrm{~mm}$ long (others: $1.68-1.79 \mathrm{~mm}$ ), reaching backwards for the first quartile of elytra; 2nd antennomere almost as long as 3rd; 
1 st to 7 th antennomere $1.8 \times$ longer than wide, 8 th to 10 th antennomere $1.6 \times$ longer than wide, 11 th antennomere $2.0 \times$ longer than wide. Pronotum convex, transverse, $1.21 \times$ as broad as long (others: $1.24-1.29 \times$ ); side margins curved with a prebasal small sinuation; anterior angles obtuse and slightly rounded; hind angles obtuse with small protruding corner. Median impression fine but well marked. Base emarginated with basal fovea clearly marked. Chaetotaxy: as in T. terrabravensis. Elytra ovate, convex with shoulders very rounded, $1.68 \times$ wider than pronotum (others: $1.60-1.66 \times$ ) and $1.37 \times$ as long as wide (others: $1.36-1.42 \times$ ). Apical angles almost sharp angled as in T. jorgensis; notch not very conspicuous. All striae well marked, with interstriae slightly convex. Chaetotaxy: as in T. terrabravensis, with setae very long and slender. Legs depigmented, similar to T. jorgensis, with protibiae not carinated; male protarsus with first two segments dilated. First metatarsomere $1.4 \times$ as long as onychium. Aedeagus with apex of median lobe more or less straight and pointed (lateral view) (figure 2a); apex subtruncated (dorsal view) (figure 2c). Left and right parameres with four setae each (figure 2b).

\section{Ecological notes}

The specimens were collected by means of liver-baited pitfall traps deep inside two small lava tubes, one located in the northeasternmost part of Pico island (Gruta do Tio Joaquim) and the other located in the central southern part of the island (Gruta das Cabras, Terra). Known from Pico island only.

\section{Taxonomic notes}

This new species is clearly similar to the troglobitic species $T$. jorgensis that occurs in the northwards close island of S. Jorge.

\section{Trechus oromii Borges, Serrano and Amorim, new species (figure 3)}

\section{Diagnosis}

Characterized by the shape of the male aedeagus. Externally very similar to $T$. picoensis. Integument clearly depigmented, colour reddish testaceous, appendages yellowish. Microreticulation isodiametric in head and pronotum, but transverse in the elytra.

\section{Type series}

Holotype: ô, Açores, Faial, Gruta do Capelo, Parque do Capelo, 28 June-18 July 2000 (I. Amorim and F. Pereira). PARATYPE: 19, same locality as holotype, 26 August-2 September 1999 (I. Amorim and F. Pereira).

Note. In addition four males and six females were collected in the same cave in 2001 for molecular analysis. These are also used for measures.

\section{Description}

Length of holotype: $4.82 \mathrm{~mm}$, convex and ovalate, the males being larger than females (average length: $4.64 \mathrm{~mm}$ for males and $4.17 \mathrm{~mm}$ for females; average width: $1.91 \mathrm{~mm}$ for males and $1.70 \mathrm{~mm}$ for females).

Head small and narrow as in $T$. picoensis, narrower than prothorax; eyes small, 

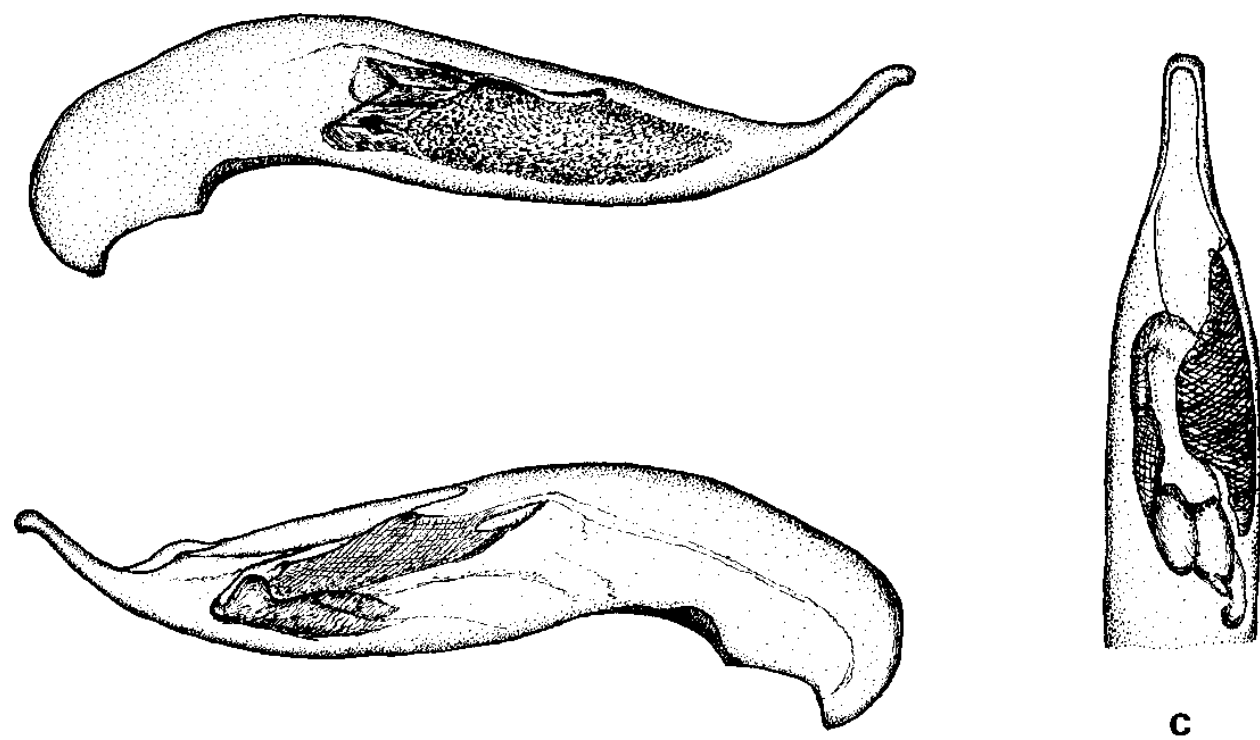

a
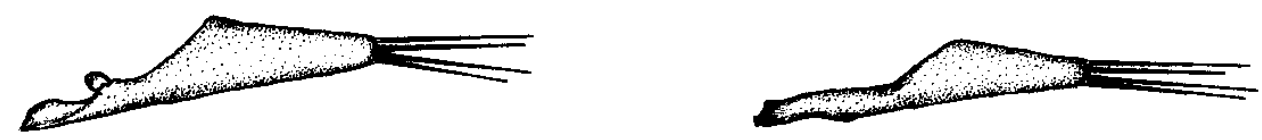

b

\section{$0.5 \mathrm{~mm}$}

FIg. 3. Aedeagus of Trechus oromii n. sp. (a) Median lobe, lateral view; (b) left and right parameres; (c) median lobe, dorsal view. Scale: $0.5 \mathrm{~mm}$.

almost flat; temples with microchaetae and $1.10 \times$ broader than eye length (others: $0.86-1.14 \times)$. Frons convex, frontal furrows deep and curved; anterior margin of labrum concave; mandibles strong and elongate. Maxillary palpi long and slender. Chaetotaxy: as in T. terrabravensis n. sp. Antennae $3.07 \mathrm{~mm}$ (other specimens: $2.55-3.20 \mathrm{~mm}$ ), reaching backwards for the first quartile of elytra; 3rd antennomere $1.27 \times$ longer than 2 nd, but quite variable (average $1.44 \times$ in males and $1.35 \times$ in females); 1 st to 3 rd antennomere $3.8 \times$ longer than wide, 4 th to 7 th antennomere $3.4 \times$ longer than wide, 8 th to 10 th antennomere $3.0 \times$ longer than wide, 11 th antennomere $3.3 \times$ longer than wide. Pronotum very similar to $T$. picoensis, convex, transverse, $1.10 \times$ as broad as long (others: $1.15-1.21 \times$ ); side margins curved in front and markedly narrowed backwards in slightly curved lines up to sharp and conspicuous protruding corners; basal margin emarginated and sinuated. Median impression fine but well marked. Basal fovea clearly marked. Chaetotaxy: as in $T$. terrabravensis n. sp. Elytra ovate, convex with rounded shoulders, $1.90 \times$ wider than pronotum (others: $1.70-1.92 \times$ ) and $1.43 \times$ as long as wide (others: 
1.42-1.55 ×). Convex with a depressed anterior field near scutellum. Elytral apex rounded and more depigmented. Chaetotaxy: as in T. terrabravensis n. sp., with setae very long and slender. Legs depigmented, long and slender. Aedeagus apex of median lobe deeply curved upwards in lateral view (figure 3a). Basal part of median lobe elongated and not so curved as in $T$. picoensis. In dorsal view the apex is narrower and longer than in $T$. picoensis (figure $3 \mathrm{c}$ ).

\section{Ecological notes}

The specimens were collected by means of pitfall traps baited with cow or pig liver deep inside of a small lava tube located in Parque do Capelo (Faial). Restricted to Faial.

\section{Taxonomic notes}

This new species is clearly similar to the troglobitic species Trechus picoensis that occurs in the nearest island of Pico.

Trechus jorgensis Oromí and Borges, 1991 (description of male)

(figure 4)

\section{Diagnosis}

Integument depigmented; antennae with the 2nd antennomere almost as long as 3rd; eyes small and very flat; apical angles of elytra almost straight. Integument depigmented, testaceous; appendages and apex of elytra more yellowish; dorsal surface dull, less shining than the other Azorean species; microreticulation isodiametric but not very precise and granulated.

\section{Studied material}

One male, Açores, S. Jorge, Algar das Bocas do Fogo, 30 June-5 August 1999 (I. Amorim and P. A. V. Borges).

\section{Description}

Length of male: $3.20 \mathrm{~mm}$ (female measured $3.05 \mathrm{~mm}$ ); width: $1.39 \mathrm{~mm}$ (female with $1.23 \mathrm{~mm})$.

Head normal, ovate, frontal furrows deep and curved; frons convex as in previous species, but the orbitals flatter in their anterior part; eyes small, clearly reduced, very flat, the diameter shorter than temples. Labrum less concave than T. terceiranus. Chaetotaxy: as in T. terrabravensis n. sp. Antennae $1.66 \mathrm{~mm}$ (1.61 $\mathrm{mm}$ in the female), reaching backwards for the first third of elytra; 3rd antennomere almost as long as $2 \mathrm{nd}$; 1 st to 7 th antennomere $2.0 \times$ longer than wide; 8 th to 10 th antennomere $1.6 \times$ longer than wide, 11 th antennomere $2.0 \times$ longer than wide. Pronotum convex, transverse, $1.27 \times$ as broad as long $(1.28 \times$ in the female). Side margins curved, with a prebasal small sinuation; anterior angles obtuse and rounded; hind angles obtuse with small protruding corners. Base emarginated; lateral fovea not very evident; side marginal furrow narrowly canaliculated; median impression fine. Chaetotaxy: as in T. terrabravensis n. sp. Elytra ovate and convex with shoulders very rounded, as in the female $1.64 \times$ wider than pronotum and $1.45 \times(1.36 \times$ in the female $)$ as long as wide. Apical angles 

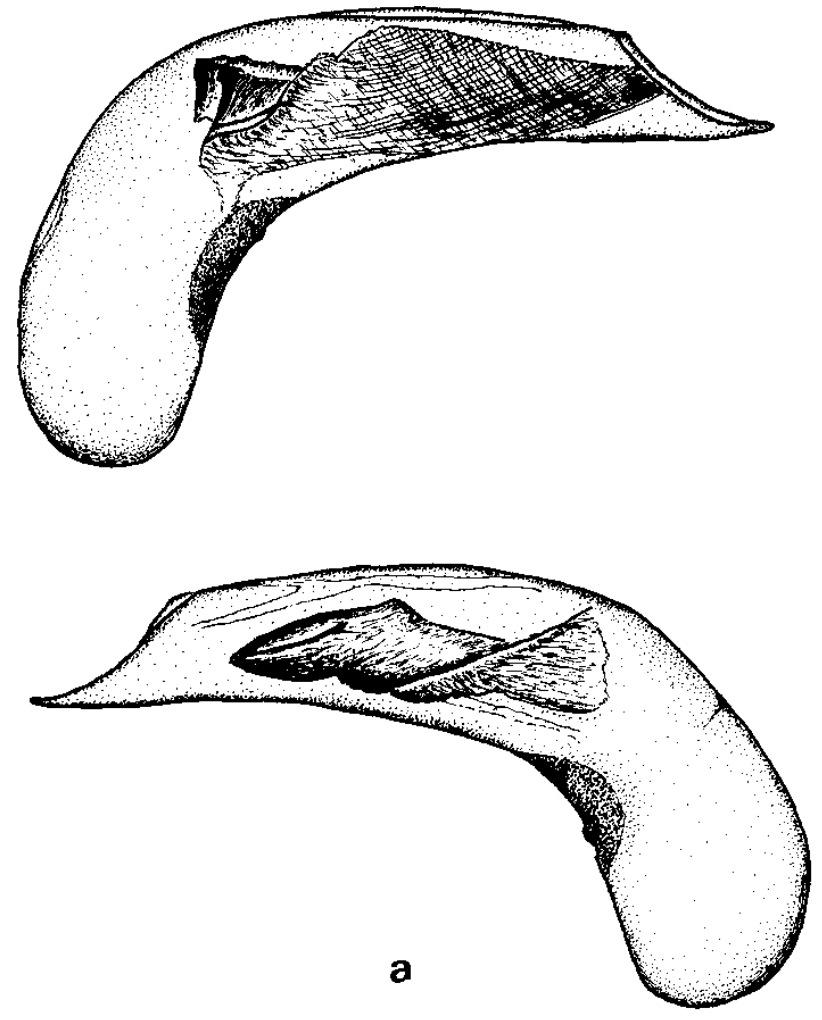

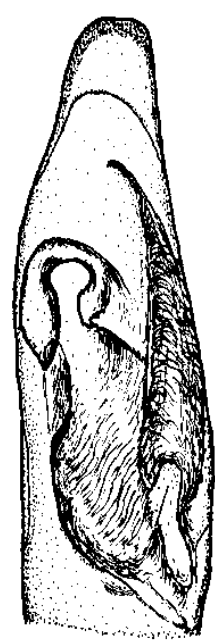

C
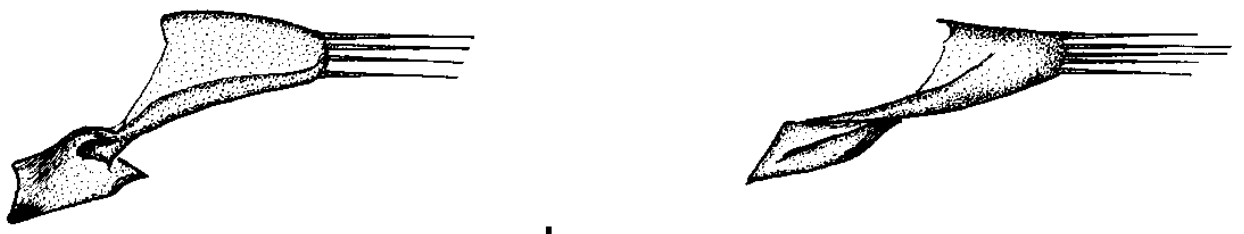

b

$0.3 \mathrm{~mm}$

FIG. 4. Aedeagus of Trechus jorgensis Oromí and Borges. (a) Median lobe, lateral view; (b) left and right parameres; (c) median lobe, dorsal view. Scale: $0.3 \mathrm{~mm}$.

forming a right angle, notch not very conspicuous. All striae well marked. Setae long and slender with the typical chaetotaxy of the Trechus spp. Preapical seta closer to the suture than to the apex.

Aedeagus with median lobe moderately arched; apex of the median lobe sharpened and slightly upward curved in lateral view (figure 4a). In dorsal view, apical lamina subtruncated (figure 4c). Left paramere with four setae and right paramere with five setae (figure $4 b$ ).

\section{Ecological notes}

The specimen was collected by means of pitfall traps baited with cow or pig liver deep inside a volcanic pit. Restricted to S. Jorge. 


\section{Taxonomic notes}

Female holotype described in Oromí and Borges (1991). This species is clearly similar to the troglobitic species Trechus pereirai $\mathrm{n}$. sp. that occurs in the nearest island of Pico, and the genitalia also with T. terrabravensis n. sp. from the island of Terceira.

\section{Key to the Azorean species of Trechus}

1 Apical angle of elytra rounded

- Apical angle of elytra pointed or sharp angled . . . . . . . . . . . . . . 6

2 Larger species, length $>3.5 \mathrm{~mm}$; lateral margins of pronotum markedly sinuated before the basis, degree of pigmentation variable . . . . . . . . . . . 3

- Length 3.0-3.2 mm; lateral margins of pronotum hardly sinuated before basis; clearly dark pigmented species . . . . . . . . . . . torretassoi Jeannel

3 Depigmented with a convex and ovalate facies; 3rd antennomere longer than 2nd . . . . . . . . . . . . . . . . . . . . . . 4

- Body pigmentation variable with lighter parts; with a transverse and depressed body; 3rd antennomere subequal to 2nd

4 Aedeagus with apex of lamella slightly blunt; only in Pico . . picoensis Machado

- Aedeagus with apex of median lobe deeply curved upwards (figure 3a); only in Faial . . . . . . . . . . . . . . . . . . . . oromii new species

5 Pronotum cordiform and highly transverse (index $\mathrm{W} / \mathrm{L}=1.35$ ), with lateral furrow very narrow . . . . . . . . . . . . . terrabravensis new species

- Pronotum index $\mathrm{W} / \mathrm{L}=1.12$; lateral furrow larger .

6 Apical angle of elytra sharp (sometimes notched), forming a small protruding point; total length $3.6-4.3 \mathrm{~mm}$. . . . . . . . . . . . terceiranus Machado

- Apical angle of elytra sharp (forming a right angle). Size $<3.5 \mathrm{~mm}$. . . . 7

7 Slightly pigmented on elytra and pronotal disc; aedeagus in lateral view with apex of median lobe more or less straight and pointed (figure 2a); right paramere with four setae (figure 2b) .

pereirai new species

- Depigmented; aedeagus in lateral view with apex of the median lobe sharpened and slightly upward curved (figure 4a); right paramere with five setae (figure 4b)

jorgensis Oromí and Borges

\section{Discussion}

With this contribution the total number of Trechus spp. (Carabidae, Trechinae) known from the Azores has been increased to eight. Trechus in the Azores can be found on five of the islands, and six out of the eight species known are confined to caves. No species are known from the most western islands, Flores and Corvo, nor from Graciosa in the Central Group and S. Maria, the oldest island of the archipelago. A noteworthy fact is the presence of three species of Trechus species on Pico island, two of them- $T$. picoensis and $T$. pereirai-being clearly troglobitic. This island is the geologically youngest island with the largest number of available lava tubes and pits (Borges et al., 1993). All Trechus species are clearly neo-endemisms.

From the analysis of the external morphology and shape of the male genitalia it is now possible to suggest the potential occurrence of at least two separate invasions of the islands by epigean colonizers. This hypothesis of a multiple invasion of the Azores is confirmed by molecular data (Amorim et al., in preparation) and is supported here by the presence of two clearly separated morphological lineages: (1) 
the aedeagus of $T$. jorgensis (S. Jorge), T. pereirai (Pico) and $T$. terrabravensis (Terceira) present a general facies resembling the aedeagus of $T$. torretassoi (epigean species from S. Miguel) and some species from Madeira (e.g. T. custos and $T$. umbricola); (2) T. terceiranus (Terceira), T. picoensis (Pico) and T. oromii (Faial) are larger species and have an aedeagus similar to the Canarian species T. flavocinctus. Curiously the epigean species from Terceira Trechus terrabravensis has an external morphology very similar to $T$. terceiranus (Terceira), besides its different type of aedeagus; and based also on the aedeagus shape, T. montanheiroum (Pico) probably also belongs to this lineage. Molecular data will eventually clarify the above hypothesis. A difficult task here is dealing with the missing species. In fact, epigean species are unknown at Pico, Faial and S. Jorge.

Another interesting fact is the atypical scarce pigmentation of the new epigean species from Terceira, Trechus terrabravensis. The same pattern could be observed in T. montanheiroum (Pico) that lives on cave entrances. The lack of pigmentation in $T$. terrabravensis could be a consequence of this species occurring in a habitat of low light - in crevices in between and within lava blocks underneath a dense forest canopy. In the Canary Islands Trechus felix occurs in laurel forests but is also lighter than other Canarian Trechus.

\section{Acknowledgements}

We are deeply grateful to Fernando Pereira ('Os Montanheiros') for his tremendous commitment with the field work. We want also to thank the important logistical support given by different people from the Azorean Forest Services at Flores, Pico, Faial, S. Jorge and S. Miguel. P. Oromí (University of La Laguna, Canary Islands) kindly reviewed early versions of this manuscript. Many thanks to Serviços Florestais dos Açores (Secretaria Regional da Agricultura e Pescas) and Governo Regional dos Açores for supporting this work under the project 'Reservas Florestais dos Açores: Cartografia e Inventariação dos Artrópodes Endémicos dos Açores' (PROJ. 17.01-080203).

\section{References}

Borges, P. A. V., and Oromí, P., 1991, The cave-dwelling ground beetles on the Azores (Col.: Carabidae), Mémoires de Biospéleologie, 18, 185-191.

Borges, P. A. V., and Oromí, P., 1994, The Azores, in C. Juberthie and V. Decu (eds) Encyclopaedia Biospeleologica, Vol.I (Moulis: Sociétè de Biospéleologie), pp. 605-610.

Borges, P. A. V., Pereira, F., and Silva, A., 1993, Caves and pits from the Azores. II. An annotated checklist, Açoreana, 7, 555-574.

Borges, P. A. V., Serrano, A. R. M., and Quartau, J. A., 2000, Ranking the Azorean Natural Forest Reserves for conservation using their endemic arthropods, Journal of Insect Conservation, 4, 129-147.

Culver, D. C., 2001, Subterranean ecosystems, in S. Levin (ed.) Encyclopaedia of Biodiversity, Vol. 5 (New York: Academic Press), pp. 527-540.

Machado, A., 1988, Two new cavernicolous species of the genus Trechus Clairv. from the Azores (Coleoptera, Carabidae), Bocagiana, 119, 1-8.

Oromí, P., and Borges, P. A. V., 1991, New Trechodinae and Trechinae from the Azores (Col.: Carabidae), Bocagiana, 152, 1-11. 